\title{
Characterisation of Temperate Urban Lacustrine Surface-Sediments for Minerals and Metals in Comparison with Geochemical Indices and Sediment Quality Criteria
}

\author{
Umar Nazir, Anisa B. Khan* \\ Department of Ecology and Environmental Sciences, Pondicherry University, Puducherry, India \\ Email: *anisabasheer@gmail.com
}

How to cite this paper: Nazir, U. and Khan, A.B. (2018) Characterisation of Temperate Urban Lacustrine Surface-Sediments for Minerals and Metals in Comparison with Geochemical Indices and Sediment Quality Criteria. Journal of Environmental Protection, 9, 1092-1112.

https://doi.org/10.4236/jep.2018.910068

Received: April 23, 2018

Accepted: September 7, 2018

Published: September 10, 2018

Copyright $\odot 2018$ by authors and Scientific Research Publishing Inc. This work is licensed under the Creative Commons Attribution International License (CC BY 4.0).

http://creativecommons.org/licenses/by/4.0/

\begin{abstract}
The present surface sediment assessment in two temperate lacustrine ecosystems in the region of anthro-urban intensification in less than a century of progressive human history identifies ecosystem responses through space-time monitoring of variable spectrum and their gradients. Sediments have almost no outliers in box-plots across the select sites that suggest their tranquil nature. But temporal fluctuations in $\mathrm{pH}$, bicarbonates, conductivity, $\mathrm{OC}, \mathrm{OM}$, $\mathrm{TN}$ and $\mathrm{C} / \mathrm{N}$ can be visualised during Ca-Si dominance. The estimated percentage elemental composition of surface sediments on dry weight basis revealed the order $\mathrm{Si}>\mathrm{Ca}>\mathrm{Mg}>\mathrm{K}>\mathrm{Na}>\mathrm{P}>\mathrm{S}>\mathrm{Cl}$. Besides, the micro and trace element quantification represent the descending series of $\mathrm{Fe}>\mathrm{Al}>\mathrm{Zn}>$ $\mathrm{Mn}>\mathrm{Cu}>\mathrm{Cr}>\mathrm{Ni}>\mathrm{Co}>\mathrm{As}>\mathrm{Sn}>\mathrm{Pb}>\mathrm{Cd}$ while $\mathrm{Hg}$ and Se remained below detection level (BDL). Sediment $\mathrm{pH}$ remained on the basic side but slight acidic nature is noticed during late summer. Significant correlation occurs for conductivity with organic $\mathrm{C}$ and organic matter $(\mathrm{p}<0.01)$ as the latter serves an established source for nutrient ions. Similar is the case with sediment organic $\mathrm{C}$, organic matter and total $\mathrm{N}$ as being complementary to one another. A general slight gradual decline in nutrient concentration till culmination of active macrophytic growth phase can be associated with active/passive bioaccumulation or anoxic release from sediments. The Enrichment Factor classifies each trace element into "No Enrichment" class to "Very High Enrichment" category. The Geochemical Index $\left(\mathrm{I}_{\mathrm{geo}}\right)$ scale labels "Unpolluted" to "Highly Polluted" element groups in sediments. The construal of Contamination Factor differentiates between "Contaminated" and "Uncontaminated" score of elements. Integrated Pollution Index (IPI) and Pollution Load Index (PLI) also categorize the sites and lakes. Sediment Quality Guidelines (SQG's)
\end{abstract}


when compared to observed mean values for various elements point to pollution status and associated ecological risks involved.

\section{Keywords}

Bicarbonate, Contamination, Fluvial, Monitoring, Trophic Index

\section{Introduction}

Sediments constitute a vital abiotic component of aquatic ecosystems and a major nutrient pool archiving historical hydroclimatic records [1]. Sediment characterisation regulates nutrient cycling and therefore contributes to overall structure and function of the system. They act as pollutant monitoring indicators of aquatic ecosystems [2] [3]. The various nutrients assimilated by aquatic organisms get incorporated into their biomass and ultimately mineralized either in organic or inorganic form in the sediments. Sediments retain nutrients [4] as well as release contaminants on disturbance [5]. The surface sediments conduct biogeochemical exchange with the overlying water column [6] depending upon the physicochemical and microbiological properties of the duo. [7] proclaimed water quality is modified on account of sediment (source) supplied contaminants facilitated by their collective physicochemical properties in the company of meteorological and hydrologic features of the watershed. The sediment-water interaction at their interface displays both ascendant and descendent exchange of chemical species [8] [9]. Expectedly higher occurrence of dissolved inorganic $\mathrm{N}\left(\mathrm{NO}_{3}^{-}+\mathrm{NO}_{2}^{-}+\mathrm{NH}_{4}^{+}\right)$in water is duly explicable because of superior accessible $\mathrm{C}, \mathrm{C} / \mathrm{N}$ and $\mathrm{S}$ content in sediments ([10] [11]. Instead, the bottom sediments act as a sink (reservoir) of nutrients [12] acquired from superimposing water suspended materials. The efficiency of sediments to act as a sink depends on the nutrient load and their absorbents presence. [13] reported that sedimentation processes are influenced by chemical composition of seston suspended waters and hydrological conditions. Eutrophic lakes and impoundments tend to be the highest depository sites for inorganic and organic $C$ forms [14] for several reasons: 1) allochthonous collection from the watershed [15]; 2) autochthonous productivity and 3) lower decomposition rates of organic matter in anoxic sediments [16]. A significant dynamics of nitrate and dissolved organic $\mathrm{N}$ contributions arise out of detritus decomposition [17].

Sediments are also a recognized sink for heavy metals that eventually alter water quality ([18]. Organic sediments immobilize the mobile metals and metalloids [19] [20]. [21] documented that metal complexation with organics may mobilize them prospectively. Conversely, calcite rich clayey lacustrine sediments dilute metal enrichment or immobilize via sorption and precipitation [22]. The $\mathrm{pH}$ parameter supplemented with anoxic conditions and OM percentage control heavy metal lability in a lake [23]. [24] designated adsorption, retention and release of nutrients and metal to prevailing control factors of $\mathrm{pH}$, temperature, 
redox state, OM and physicochemical composure of sediments. [25] attempted to delineate the derivation of $\mathrm{CaCO}_{3}$ in lacustrine sediments by declaring a high Ca:Al proportion indicative of endogenic source. [26] concluded in situ geochemical weathering (origin) followed by carbonate precipitation within a reservoir at $\mathrm{Ca} / \mathrm{Al}$ values $\geq 10$. Accordingly, observed higher content of $\mathrm{Al}$ and other metals equated to Ca suggest transported ex situ anthropogenic and lithogenic sources. The severity of metal pollution in aquatic ecosystems is effectively comprehended by adapting various sediment quality indices [27].

\section{Materials and Methods}

The north-west Himalayan biogeographic zone of India embeds the state of Jammu and Kashmir (Figure 1) at an altitude $\geq 1500 \mathrm{~m}$ a.s.l. The temperate climatic valley has about $64 \%$ mountainous physiography with the Great Himalayas in its North and Pir Panjal range in its South. Kashmir is characterized by an array of natural lacustrine water bodies upholding paramount ecological, cultural, historical and socio-economic significance. The estimated geographic area occupied by lakes in J \& $\mathrm{K}$ is 13762 ha that approximates to $3.52 \%$ of all its aquatic ecosystems (National Wetland Atlas, 2010). The city of Srinagar $\left(33^{\circ} 59^{\prime} 14^{\prime \prime}-34^{\circ} 12^{\prime} 37^{\prime \prime} \mathrm{N}\right.$ latitudes and $74^{\circ} 41^{\prime} 06^{\prime \prime}-74^{\circ} 57^{\prime} 27^{\prime \prime} \mathrm{E}$ longitudes) sited on the banks of the Jhelum (Vyeth) spreads across the plains of Kashmir vale. It has a moderate physiography $\geq 1580 \mathrm{~m}$ a.s.l. representing hill-topography. The general climatic conditions resemble the sub-Mediterranean characterized by yearlong precipitation episodes except a few summer and autumn dry-periods, besides, both seasonal and diurnal extremes of temperature. During the course of study, the monthly maximum, mean and minimum temperatures $\left({ }^{\circ} \mathrm{C}\right)$ and average rainfall $(\mathrm{mm})$ at Srinagar is illustrated in Figure 2. The lake area cover of Srinagar is 2194 ha equivalent to $21.76 \%$ of its total wetland area. The very existence of the urban lacustrine water bodies is under continuously intensifying multiple stressors of nutrient loading, siltation, waste disposal, sewerage and agro-chemical residue receivers, expanding floating-garden area, encroachment, blockade and narrowing of drainage channels, hydrological alterations, catchment

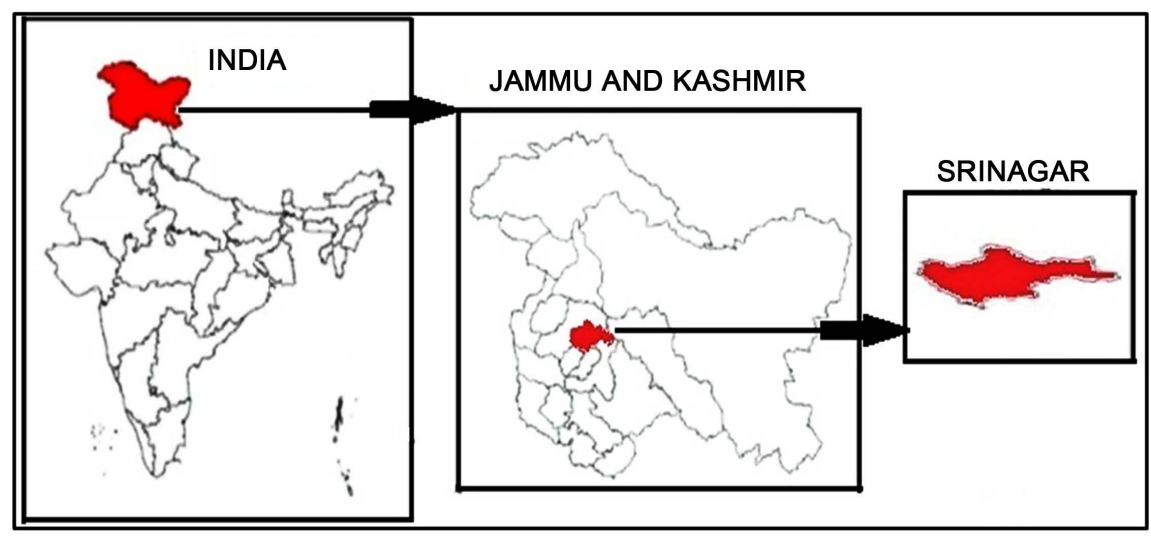

Figure 1. The summer capital (Srinagar) of Jammu and Kashmir. 


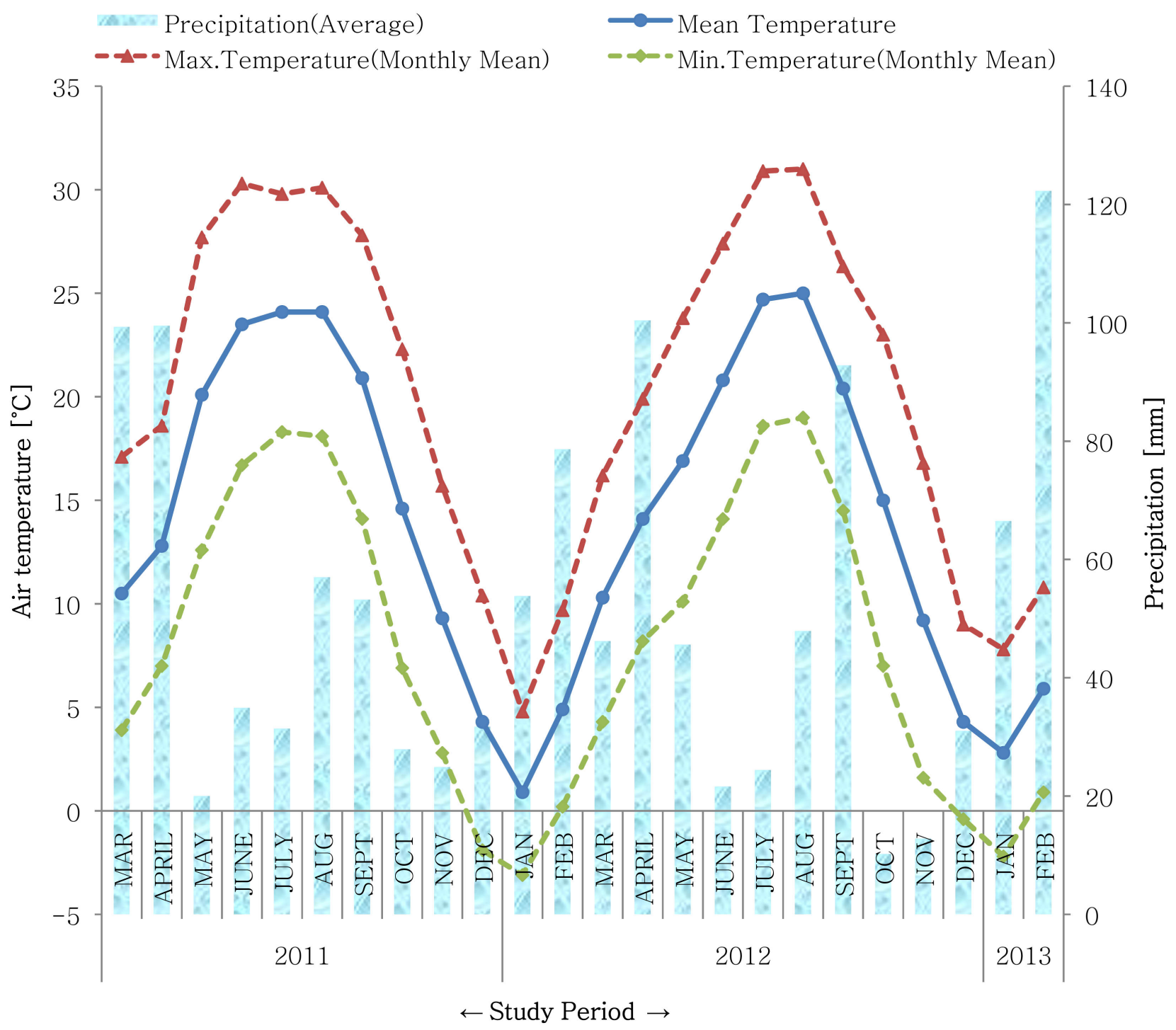

Figure 2. Climate profile of Srinagar 2011-2013 (Data source: India Meteorological Department).

perturbations and so on [28] [29]. The focuses of present limnological research remain two fluvial urban valley lakes namely Anchar and Dal situated in the summer capital (Srinagar) of J \& K. Anchar is a single basined lake located in the north-west of Srinagar city within the geographical coordinates of $34^{\circ} 20^{\prime}$ $34^{\circ} 26^{\prime} \mathrm{N}$ latitudes and $74^{\circ} 82^{\prime}-74^{\circ} 85^{\prime} \mathrm{E}$ longitudes. It has fluvial origin and occupies about $6 \mathrm{~km}^{2}$ water surface area at an altitude of $1584 \mathrm{~m}$ a.s.l. [30]. Its mean depth is about $1.6 \mathrm{~m}$ and has a catchment cover of $\sim 66 \mathrm{~km}^{2}$. It has an open drainage feature reflected by a feeding network of streams from river Sindh; Gilsar-Khushalsar lake connections besides natural basin springs while its exit contributes to the Jhelum waters. While as the geographical position of Dal lake is in north-east of Srinagar city at $1587 \mathrm{~m}$ a.s.l. altitude occupying the coordinates of $34^{\circ} 04^{\prime} \mathrm{N}$ to $34^{\circ} 09^{\prime} \mathrm{N}$ and $74^{\circ} 49^{\prime} \mathrm{E}$ to $74^{\circ} 52^{\prime} \mathrm{E}$ Space Applications Centre, ISRO, Ahmedabad, India, 176. It is a tetra-basined ox-bow type lake formed by meandering course of river Jhelum. Its main feeding source is a perennial Dachigam 
creek (splitted into 3 streams of Telbal, Pishpu and Meerakshah) and several lake-bed springs, however, the key exit discharges via Dalgate into the Jhelum. Alternate hydro energy center (AHEC), Roorkee designates an area of $337 \mathrm{~km}^{2}$ as its catchment while holding a water volume of $15 \times 10^{6} \mathrm{~m}^{3}$. The satellite imagery database of Lakes and Waterways Development Authority (LWDA)-2007 reveals its total area as $24.6 \mathrm{Km}^{2}$ with an open water expanse of $15.41 \mathrm{Km}^{2}$ and the remaining occupied by floating gardens, emergent vegetation zone, house boats and human settlement area. A recent assessment intimates the open water spread restricted to just $10.5 \mathrm{Km}^{2}$ [31]. The mean depth averages to $<3 \mathrm{~m}$ while the maximum depth equals $6 \mathrm{~m}$.

The inter-annual survey, sample collection and chemo-sediment study of the two lakes carried out from March, 2011 to February, 2013 is based on their 5 select stations. The five locations (Table 1) designated as A1, A2, D1, D2 and D3 were each further fragmented into ten sampling stations (indicative as red spots in Figure 3) in order to obtain composite representative samples in triplicate for enhanced precision. The site selection criterion implemented here represents the distinct spatial features within the lakes. A1 adjoins the urban locale highly infested with vegetation and diffuse sewage inputs; A2 is situated closer to the lakes' exit and recipient of run-off from paddy fields; D1 vicinity is contributed with key inlet and STP discharges; D2 typifies the floating garden area; and D3 nearby the outlet has hotel and house-boat zone. Surface sediment samples are collected with the help of shovel and Ekman dredge ( $\sim$ to $25 \mathrm{~cm}$ depth) at the selected sites from both the lakes on seasonal basis for the study period of two years. In order to reduce heterogeneous nature of sediments due to changes in hydrological regime and catchment area geomorphology, composite samples are constituted by mixing at least 5 sub-samples taken from each sampling station. Except $\mathrm{pH}$ and electrical conductivity all the parameters are carried out on oven dried samples following standard recommended methods from [32] [33] [34] [35]. The sediment analysis includes $\mathrm{H}$-ion concentration, electrical conductivity, bicarbonates, organic- $\mathrm{C}$, organic matter, total- $\mathrm{N}, \mathrm{C} / \mathrm{N}$ ratio, elemental composition of $\mathrm{Ca}, \mathrm{Cl}, \mathrm{K}, \mathrm{Mg}, \mathrm{Na}, \mathrm{P}, \mathrm{S}, \mathrm{Si}$ and trace elements for each season.

Hydrogen ion concentration: $\mathrm{pH}$ of fresh sediments is determined within 24 hours of sampling using an Elico (India) make pH meter (model 181E). A suspension $(1: 2.5 \mathrm{~W} / \mathrm{V})$ of $10 \mathrm{~g}$ sediment added to $25 \mathrm{~mL}$ of distilled water is prepared by constant stirring and allowed to settle down turbidity in order to take

Table 1. Coordinates of sampling locations.

\begin{tabular}{ccc}
\hline Site & Latitude & Longitude \\
\hline A1 & $34^{\circ} 8^{\prime} 24^{\prime \prime} \mathrm{N}$ & $74^{\circ} 47^{\prime} 41^{\prime \prime} \mathrm{E}$ \\
A2 & $34^{\circ} 8^{\prime} 37^{\prime \prime} \mathrm{N}$ & $74^{\circ} 46^{\prime} 52^{\prime \prime} \mathrm{E}$ \\
D1 & $34^{\circ} 8^{\prime} 35^{\prime \prime} \mathrm{N}$ & $74^{\circ} 51^{\prime} 17^{\prime \prime} \mathrm{E}$ \\
D2 & $34^{\circ} 7^{\prime} 56^{\prime \prime} \mathrm{N}$ & $74^{\circ} 51^{\prime} 44^{\prime \prime} \mathrm{E}$ \\
D3 & $34^{\circ} 5^{\prime} 53^{\prime \prime N}$ & $74^{\circ} 51^{\prime} 18^{\prime \prime} \mathrm{E}$
\end{tabular}




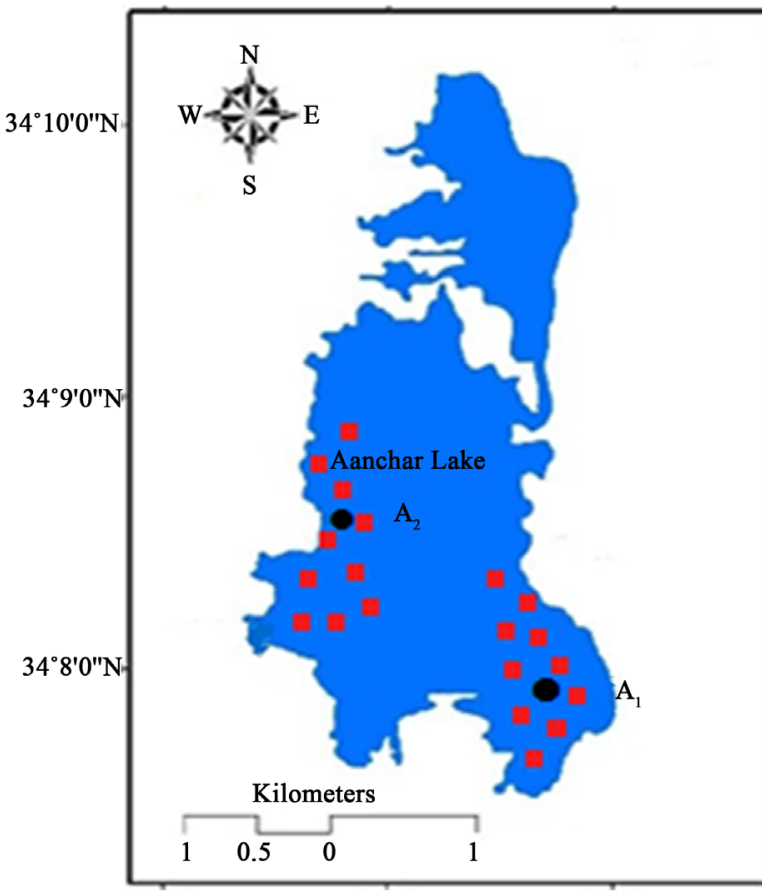

$74^{\circ} 46^{\prime} 0^{\prime \prime} \mathrm{E}$

$74^{\circ} 47^{\prime} 0^{\prime \prime} \mathrm{E}$

$74^{\circ} 48^{\prime} 0^{\prime \prime} \mathrm{E}$

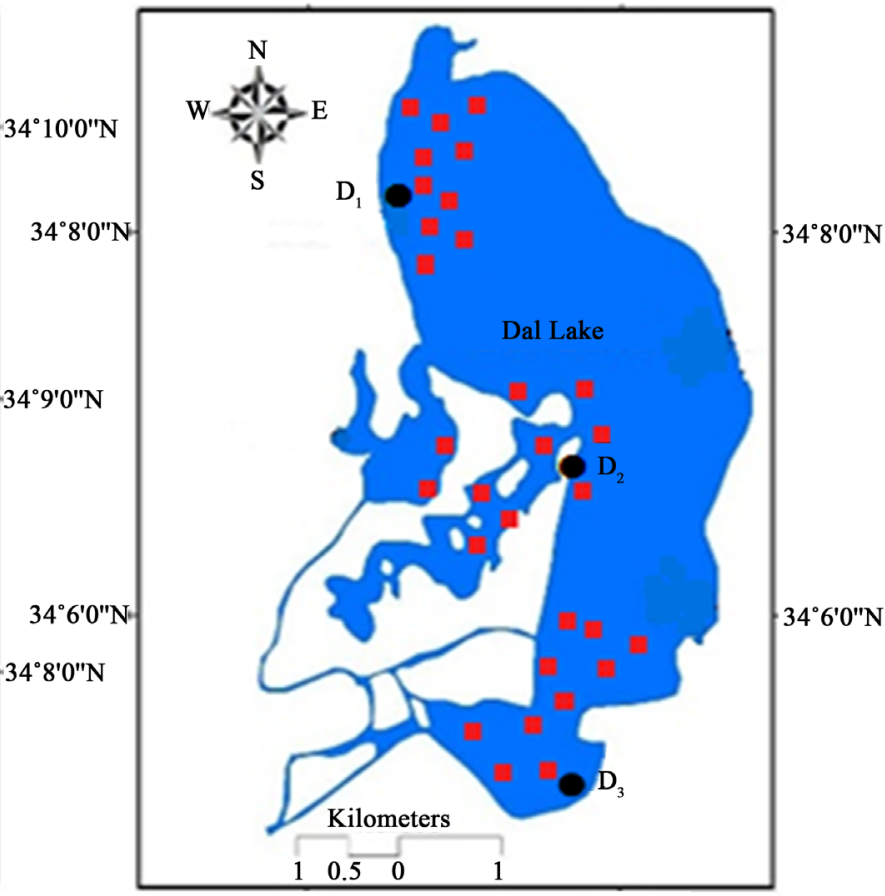

$74^{\circ} 50^{\prime} 0^{\prime \prime} \mathrm{E}$

$74^{\circ} 52^{\prime} 0^{\prime \prime} \mathrm{E}$

Figure 3. Sample collection stations.

replicate $\mathrm{pH}$ meter readings. The instrument is calibrated with standard buffer solutions of known $\mathrm{pH}(4,7$ or 9.2). The electrode is flushed with distilled water before each immersion in the supernatant suspension and the buffer solution.

Electrical Conductivity: A clear filtrate of 1:2 W/V sediment-distilled water suspension (40 g sediment in $80 \mathrm{~mL}$ of distilled water) is prepared to determine conductivity. An Elico make and model CM 180 conductivity meter calibrated at $1413 \mu \mathrm{S} \cdot \mathrm{cm}^{-1}$ using a standard $0.01 \mathrm{M} \mathrm{KCl}$ solution is used to check conductivity at room temperature.

Bicarbonates: For the determination of $\mathrm{HCO}_{3}^{-}$anions, a 1:2 sediment-distilled water extract is prepared by mixing $250 \mathrm{~g}$ of sediment in $500 \mathrm{~mL}$ of distilled water on a shaker for about 20 minutes. $20 \mathrm{~mL}$ of the filtered extract is titrated against $0.02 \mathrm{~N} \mathrm{H}_{2} \mathrm{SO}_{4}$ thrice to obtain concordant anion(s) concentration using methyl orange as indicator. The results reported in $\mathrm{mg} \cdot \mathrm{Kg}^{-1}$ are calculated using the formula: $\mathrm{HCO}_{3}^{-}\left(\mathrm{mg} \cdot \mathrm{L}^{-1}\right)=\left(\mathrm{V}_{1}-\mathrm{V}_{2}\right) \times \mathrm{N} \times \mathrm{e} / \mathrm{V}_{3} \times 1000$ where $\mathrm{V}_{1}=$ volume of titrant used for neutralization of bicarbonates in the sample $(\mathrm{mL})$ for methyl orange end-point; $\mathrm{V}_{2}=$ volume of titrant used for the blank $(\mathrm{mL}) ; \mathrm{V}_{3}=$ volume of sample used $(50 \mathrm{~mL}) ; \mathrm{N}=$ normality of $\mathrm{H}_{2} \mathrm{SO}_{4}$ standard solution (0.02 $\mathrm{N})$ and $\mathrm{e}=$ equivalent weight of $\mathrm{HCO}_{3}^{-}(61 \mathrm{~g})$.

Organic Carbon and Organic matter: $0.5 \mathrm{~g}$ of oven dried sediment sample is used for organic $\mathrm{C}$ estimation by Walkley and Black wet oxidation method. 10 $\mathrm{mL}$ of $1 \mathrm{~N} \mathrm{~K}_{2} \mathrm{Cr}_{2} \mathrm{O}_{7}$ solution in presence of $20 \mathrm{~mL}$ concentrated $\mathrm{H}_{2} \mathrm{SO}_{4}$ along with the sample is gently swirled in a flask to mix and then allowed to stand for 30 
minutes in order to oxidise organic matter in the sample. The excess $\mathrm{K}_{2} \mathrm{Cr}_{2} \mathrm{O}_{7}$ not reduced by the organic matter is determined by back titrating with $0.5 \mathrm{~N}$ ferrous ammonium sulphate using diphenyl amine as indicator to a violet-blue endpoint after adding $200 \mathrm{~mL}$ double distilled water, $10 \mathrm{~mL}$ of phosphoric acid and a pinch of sodium fluoride to the sample. A reagent blank is run simultaneously. The amount of organic $\mathrm{C}$ present in Percentage of Organic Carbon (\% $\mathrm{C})=[0.003 \times 10(\mathrm{~B}-\mathrm{C}) / \mathrm{B} \times \mathrm{W} \times 100] 1.3$ where $0.003 \mathrm{~g} \mathrm{C}=1 \mathrm{~mL}$ of $1 \mathrm{~N}$ $\mathrm{K}_{2} \mathrm{Cr}_{2} \mathrm{O}_{7} ; 10(\mathrm{~B}-\mathrm{C}) / \mathrm{B}=$ volume of $1 \mathrm{~N} \mathrm{~K}_{2} \mathrm{Cr}_{2} \mathrm{O}_{7}$ used for $\mathrm{C}$ oxidation; $\mathrm{B}=$ volume of $0.5 \mathrm{~N}$ ferrous ammonium sulphate to neutralize $10 \mathrm{~mL} 1 \mathrm{~N} \mathrm{~K}_{2} \mathrm{Cr}_{2} \mathrm{O}_{7}$ in blanks' titration $(\mathrm{mL}) ; \mathrm{C}=$ volume of $0.5 \mathrm{~N}$ ferrous ammonium sulphate used for titrating sample $(\mathrm{mL}) ; \mathrm{W}=$ weight of sediment sample and 1.3 is a correction factor for incomplete (77\%) oxidation of organic matter. The organic matter content is determined from the above established organic $\mathrm{C}$ percentage and is calculated as: Percent Organic Matter $(\% \mathrm{OM})=\% \mathrm{C} \times 1.724$ where $1.724=$ Van Bemmelen factor assuming organic matter contains $58 \%$ of organic $\mathrm{C}$.

Total Nitrogen: It is estimated by Kjeldahl method using $0.5 \mathrm{~g}$ of oven dried and $0.425 \mathrm{~mm}$ sieved sediment sample. $20 \mathrm{~mL}$ concentrated $\mathrm{H}_{2} \mathrm{SO}_{4}$ in presence of $1 \mathrm{~g} \mathrm{~K}_{2} \mathrm{SO}_{4}$ and $0.5 \mathrm{~g} \mathrm{CuSO}_{4}$ is used to digest the sample till it turns torquoise. The volume of digest is raised upto $100 \mathrm{~mL}$ with distilled water after cooling. The contents are now distilled along with strong alkali $(40 \% \mathrm{NaOH})$ and the ammonia liberated is collected in boric acid absorbing solution with the mixed indicator. The resultant greenish ammonium borate in the receiving solution is back titrated with standard $0.02 \mathrm{~N} \mathrm{HCl}$ till pinkish endpoint. A blank titration is also carried out for calculation of total $\mathrm{N}$ as percentage dry weight basis. $\% \mathrm{Ni}$ trogen in Sediment $=(\mathrm{S}-\mathrm{B}) \times \mathrm{N} \times 1.401 / \mathrm{W}$ where $\mathrm{S}=$ volume of standard $\mathrm{HCl}$ titrant used for the sample $(\mathrm{mL}) ; \mathrm{B}=$ volume of standard acid used for the blank $(\mathrm{mL}) ; \mathrm{N}=$ normality of $\mathrm{HCl}$ and $\mathrm{W}=$ weight of sample $(\mathrm{g})$.

C/N Ratio: Carbon and nitrogen stoichiometry in sediments is calculated from the results of above given allied methods.

The multi-elemental quantification of $\mathrm{Ca}, \mathrm{Cl}, \mathrm{K}, \mathrm{Mg}, \mathrm{Na}, \mathrm{P}, \mathrm{S}$ and $\mathrm{Si}$ in sediments is performed using wavelength dispersive $\mathrm{X}$-ray fluorescence spectrometer (WD-XRF) at central instrumentation facility (CIF), Pondicherry University. $1 \mathrm{~g}$ of oven dried, finely ground and sieved $(0.425 \mathrm{~mm} / 420$ micron mesh) sediment sample is used. A homogeneous sample is prepared with 1:4 ratio borate flux [36] for the quantitative analysis on WD-XRF spectrometer of Bruker S4 Pioneer make and model.

However, the trace elements were determined at sophisticated analytical instrument facility (SAIF) IITM, Chennai using ICP-OES (Perkin Elmer Optima 5300 DV) instrument. The simultaneous PTE quantification in lake sediment follow manufacturer's standard operating procedures and conditions. The analyte concentrations in the extract solutions are reported as $\mathrm{mg} \cdot \mathrm{Kg}^{-1}$ on dry weight basis using the following W/V correction equation: Sample concentration $\left(\mathrm{mg} \cdot \mathrm{Kg}^{-1}\right)=\mathrm{C} \times \mathrm{V} / \mathrm{W}$ where $\mathrm{C}=$ concentration in the extract $\left(\mathrm{mg} \cdot \mathrm{L}^{-1}\right) ; \mathrm{V}=$ volume of extract $(100 \mathrm{~mL}$ or $0.1 \mathrm{~L})$ and $\mathrm{W}=$ weight of sample $(1 \mathrm{~g}$ or $0.001 \mathrm{Kg})$. 
Further, the descriptive and illustrative statistical analysis is performed using MS-Excel 2010, PAST 3 and SPSS 19. The extrapolation, graphic visualization and interpretation of statistical procedures and scores are based on [37] [38].

\section{Results}

Sediment characterisation featuring seasonal quantification marks a distinctive outcome. The boxplots of analysed parameters pronounce site wise trend in Figure 4. The observed range of $\mathrm{H}$-ion concentration in surface sediments is 6.16 to 8.35 and the respective mean site values include $7.22 \pm 0.60,7.30 \pm 0.64$, $7.58 \pm 0.42,7.20 \pm 0.58,7.49 \pm 0.56$. Sediment conductivity ranged between 234 and $498 \mu \mathrm{S} \cdot \mathrm{cm}^{-1}$ at $25^{\circ} \mathrm{C}$ and the average inter-site comparison is as $395.4 \pm 55.7$, $312.6 \pm 47.2,293.3 \pm 36.4,363.3 \pm 50.9$ and $323.3 \pm 38.4 \mu \mathrm{S} \cdot \mathrm{cm}^{-1}$ respectively. The sediment bicarbonate content has minima of 116 and maxima of 264 $\mathrm{mg} \cdot \mathrm{Kg}^{-1}$ and varied between the designated sites as $187.4 \pm 25.3,193.5 \pm 37.2$, $169.8 \pm 41.5,172.6 \pm 41.9$ and $189.6 \pm 42.3 \mathrm{mg} \cdot \mathrm{Kg}^{-1}$ correspondingly. The ranges and average site wise percentage dry-weight variations in sediment organic $\mathrm{C}$ $(\mathrm{OC})$, organic matter $(\mathrm{OM})$, total $\mathrm{N}(\mathrm{TN})$ and $\mathrm{C} / \mathrm{N}$ ratio are summarized in $\mathrm{Ta}-$ ble 2 and visualised in Figure 5. The assessed average percentage elemental composition of surface sediment on DW basis (Figure 6) revealed a slight inter-seasonal variance and follow the dominance order of $\mathrm{Si}>\mathrm{Ca}>\mathrm{Mg}>\mathrm{K}>$ $\mathrm{Na}>\mathrm{P}>\mathrm{S}>\mathrm{Cl}$. Besides, the average micro- and trace-element quantification (Figure 7) remained seasonally almost uniform and represent the descending series of $\mathrm{Fe}>\mathrm{Al}>\mathrm{Zn}>\mathrm{Mn}>\mathrm{Cu}>\mathrm{Cr}>\mathrm{Ni}>\mathrm{Co}>\mathrm{As}>\mathrm{Sn}>\mathrm{Pb}>\mathrm{Cd}$ while $\mathrm{Hg}$ and Se as BDL.

The above acquired data for sediment metal profile paved way for Pollution Indices and Sediment Quality Criteria adoption.

1) Enrichment Factor (EF) calculations are based on comparison with background levels from global average composition [39]. EF is determined according to [40] definition as the observed Metal/Fe ratio in the sediment sample divided by natural background value of the Metal/Fe ratio. Devoid of any real background or reference values, average crustal composition from [41] are adopted to serve as preindustrial levels. Fe being an immobile element due to vast natural sources and dominant input is used to normalize heavy metal contamination [42]. The calculation of EF in Table 3 classifies each trace element into "No Enrichment" to "Very High Enrichment" classes of sediment samples collected

Table 2. \% ( \pm S.D.) Organic Carbon (OC), Organic Matter (OM), Total Nitrogen (TN) and $\mathrm{C} / \mathrm{N}$ ratio in select site sediments

\begin{tabular}{cccccc}
\hline Sediment-Variable & RANGE & A2 & D1 & D2 & D3 \\
\hline OC (\%) & 6.7 to 15.21 & $9.42 \pm 1.58$ & $8.67 \pm 0.84$ & $9.83 \pm 1.27$ & $7.85 \pm 0.77$ \\
OM (\%) & 11.55 to 26.22 & $16.238 \pm 2.726$ & $14.940 \pm 1.442$ & $16.939 \pm 2.178$ & $13.526 \pm 1.327$ \\
TN (\%) & 1.09 to 2.87 & $1.828 \pm 0.322$ & $1.864 \pm 0.306$ & $1.900 \pm 0.174$ & $2.458 \pm 0.322$ \\
C/N RATIO & 2.55 to 7.53 & $5.208 \pm 0.720$ & $4.789 \pm 0.948$ & $5.175 \pm 0.554$ & $3.229 \pm 0.373$ \\
\hline
\end{tabular}



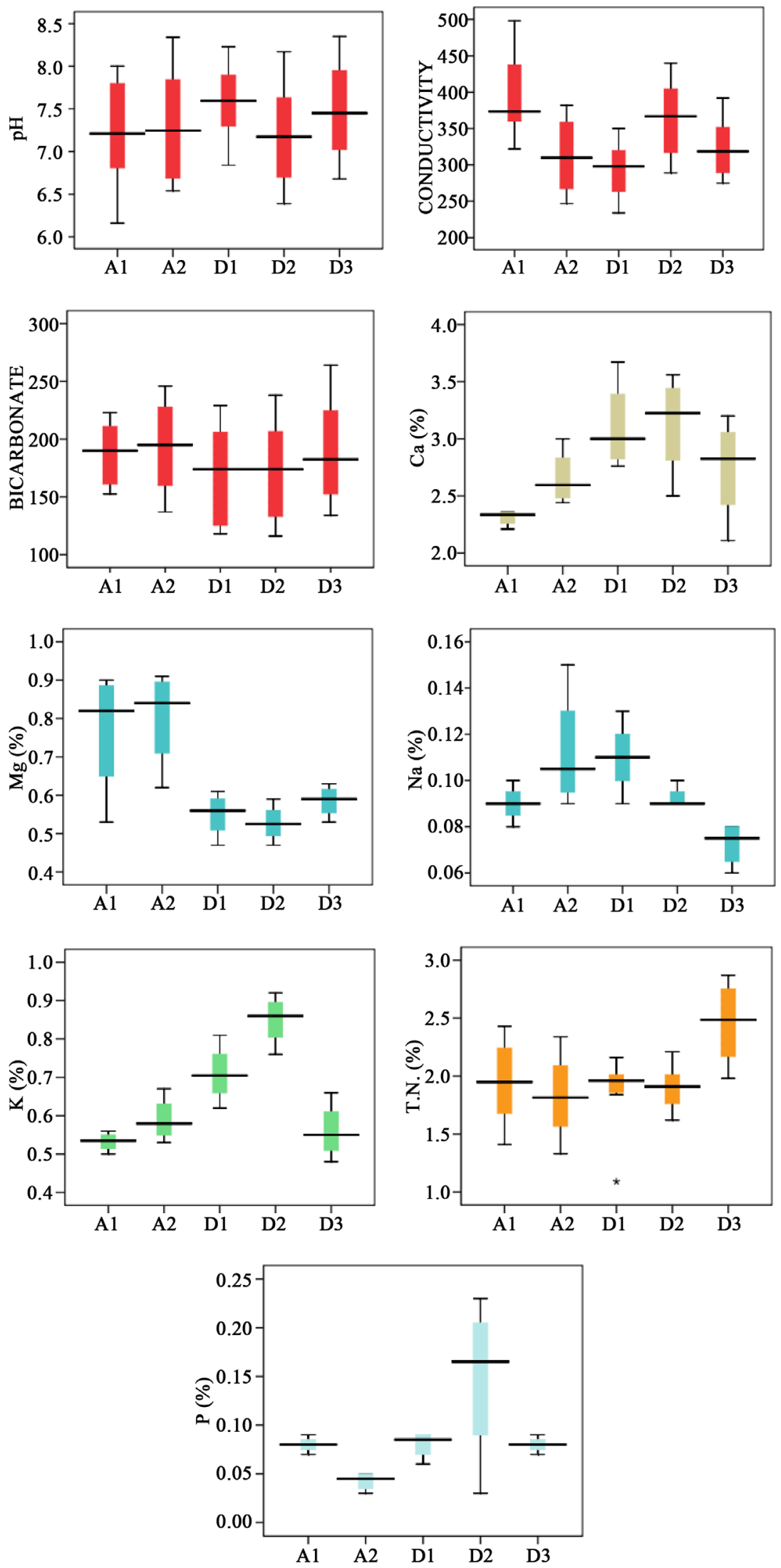

Figure 4. Boxplots of sediment parameters. 

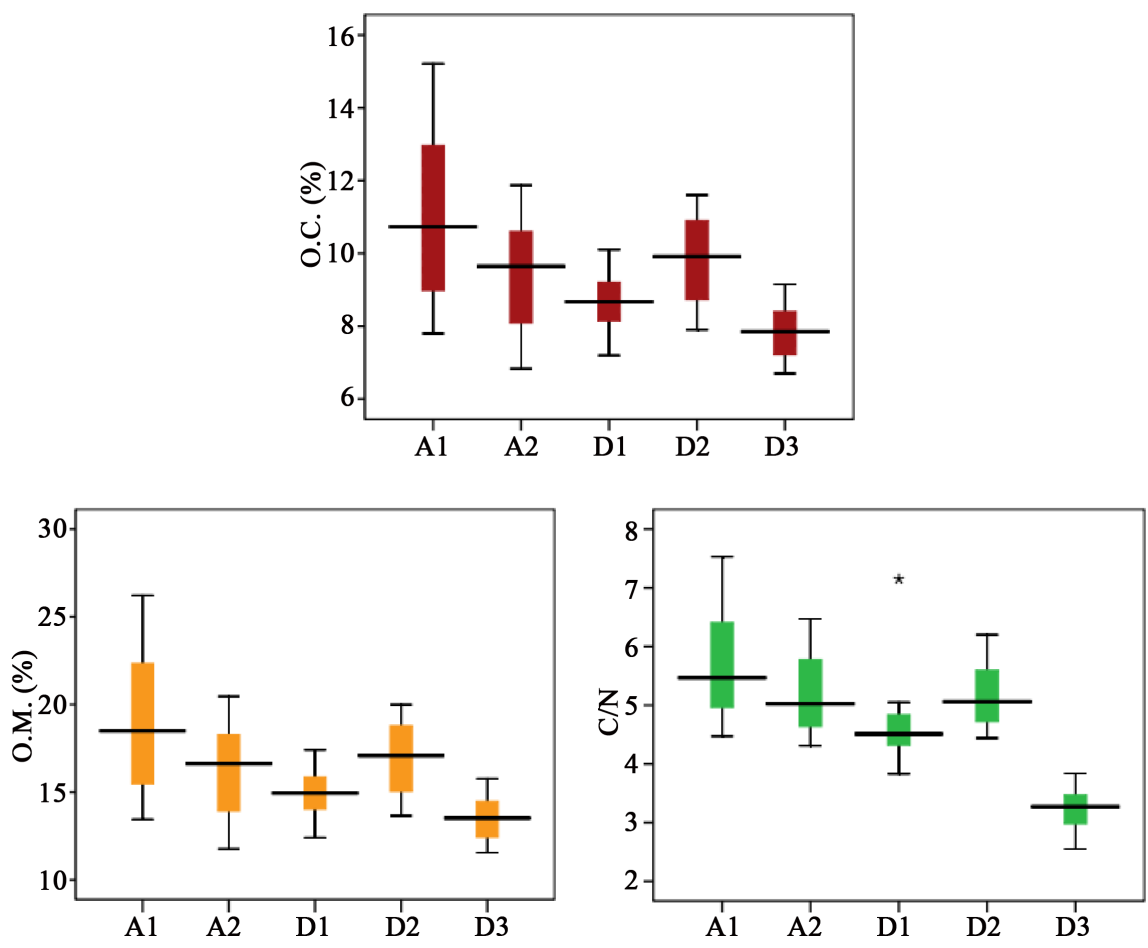

Figure 5. Boxplots of organic-C, organic-matter and C/N.

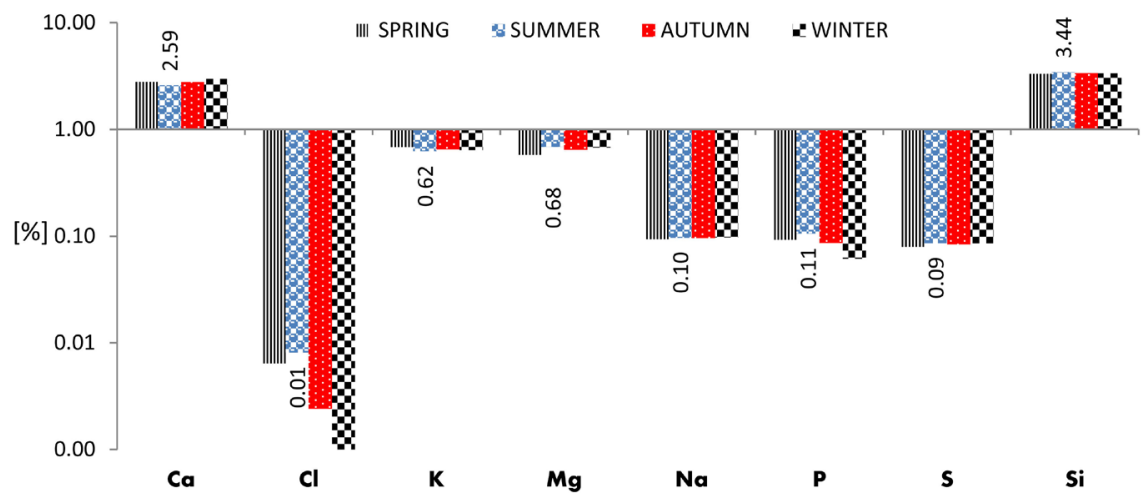

Figure 6. Average percentage elemental composition of surface sediments.

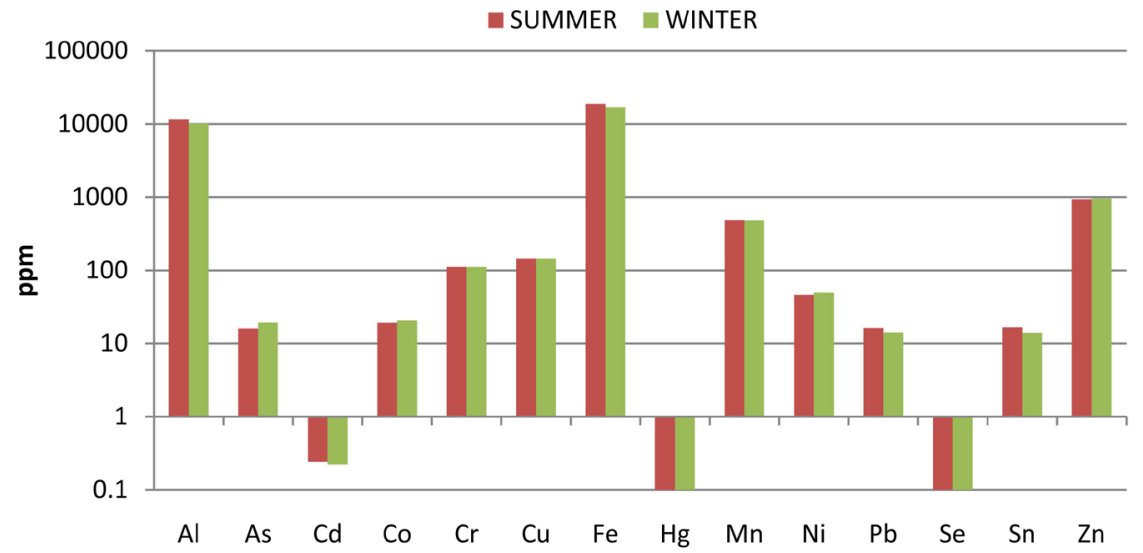

Figure 7. Mean micro- and trace-element quantification. 
Table 3. Elemental enrichment factor (EF) and \% EF classification of elements (Han et al., 2006).

\begin{tabular}{cccccccc}
\hline Symbol & $\mathrm{EF}_{[\text {COMBINED }]}$ & $\% \mathrm{EF}$ & $\mathrm{EF}_{[\mathrm{ANCHAR}]}$ & $\% \mathrm{EF}$ & $\mathrm{EF}_{[\mathrm{DAL}]}$ & $\% \mathrm{EF}$ & EF INTERPRETATION \\
\hline $\mathrm{Al}$ & 0.2 & 57.7 & 0.2 & 59.0 & 0.25 & 57.37 & NO ENRICHMENT $(<1)$ \\
$\mathrm{As}$ & 22.0 & 20.9 & 24.0 & 23.6 & 20.43 & 30.77 & VERY HIGH $(20-40)$ \\
$\mathrm{Cd}$ & 4.5 & 42.4 & 3.7 & 33.3 & 5.02 & 48.52 & $\operatorname{MODERATE~}(2-5)$ \\
$\mathrm{Co}$ & 2.3 & 41.7 & 2.3 & 47.1 & 2.29 & 38.72 & $\operatorname{MODERATE~}(2-5)$ \\
$\mathrm{Cr}$ & 2.6 & 64.4 & 2.6 & 75.7 & 2.56 & 55.94 & $\operatorname{MODERATE}(2-5)$ \\
$\mathrm{Cu}$ & 10.9 & 29.5 & 10.0 & 24.8 & 11.53 & 30.73 & $\operatorname{SIGNIFICANT~}(5-20)$ \\
$\mathrm{Fe}$ & 1.0 & 37.6 & 1.0 & 37.1 & 1.00 & 35.24 & $\operatorname{MiNOR}(<3)$ \\
$\mathrm{Mn}$ & 1.4 & 43.5 & 1.5 & 51.0 & 1.34 & 38.63 & $\operatorname{MiNOR}(<3)$ \\
$\mathrm{Ni}$ & 1.9 & 40.3 & 1.9 & 43.0 & 1.93 & 38.07 & $\operatorname{MiNOR}(<3)$ \\
$\mathrm{Pb}$ & 1.6 & 54.5 & 1.3 & 47.4 & 1.79 & 57.79 & $\operatorname{MiNOR}(<3)$ \\
$\mathrm{Sn}$ & 4.5 & 51.7 & 5.9 & 60.0 & 3.41 & 27.30 & $\operatorname{MODERATE}(5-20)$ \\
$\mathrm{Zn}$ & 26.4 & 34.7 & 27.0 & 32.1 & 26.03 & 35.52 & $\operatorname{VERY~HIGH~}(20-40)$ \\
\hline
\end{tabular}

from the study stations in accordance to [43] interpretation. Besides, Percentage Enrichment Factor (EF \%) for each element is calculated as per [44] by applying the equation: $\% \mathrm{EF}=\mathrm{C}-\mathrm{C}_{\min } / \mathrm{C}_{\max }-\mathrm{C}_{\min } \times 100$ where $\mathrm{C}=$ mean total concentration of an element; $\mathrm{C}_{\min }=$ the minimum metal concentration and $\mathrm{C}_{\max }=$ the maximum metal concentration.

2) Geo-accumulation Index ( $\mathrm{I}_{\text {geo }}$ ) is a quantitative criterion originally propounded by [45] to measure pollution intensity on a given qualitative scale [46] and [47] as $I_{\text {geo }}=\log _{2}\left(C_{n} / 1.5 B_{n}\right)$ where $C_{n}=$ measured concentration of an examined element $(n)$ in the enriched sediment; $B_{n}=$ geochemical background concentration of the element (n) and 1.5 is the matrix correction factor to minimize possible lithogenic differences in the control values ([48]. Here the world's crustal surface average composition by [41] is used as the geochemical background. The measures of $\mathrm{I}_{\text {geo }}$ scale in Table 4 labels "Unpolluted" to "Highly Polluted" element groups in sediments [47].

3) Contamination Factor (CF) connotes to a fraction of mean content of an element $\left(\mathrm{C}_{\mathrm{i}}\right)$ as antecedent and its pre-industrial level $\left(\mathrm{C}_{\mathrm{n}}\right)$ as consequent, viz, CF $=\mathrm{C}_{\mathrm{i}} / \mathrm{C}_{\mathrm{n}}$. The construal of CF differentiates between "Contaminated" and "Uncontaminated" score of elements in Table 5 as per [49].

4) Integrated Pollution Index (IPI) is the mean value of single factor pollution index (PI) for each element which in turn denotes the fraction of $\mathrm{C}_{\mathrm{n}}$ (observed metal concentration) and $\mathrm{B}_{\mathrm{n}}$ (baseline metal concentration) [50]. Again, Pollution Load Index (PLI) provides an integrated and site-wise comparative assessment of cumulative heavy metal pollution [51]. It is given as the nth root of the product of $\mathrm{n}$ contamination factor values, viz, $\mathrm{PLI}=\left(\mathrm{CF}_{1} \times \mathrm{CF}_{2} \times \mathrm{CF}_{3} \times \cdots \times\right.$ $\left.\mathrm{CF}_{n}\right)^{1 / n}$ where $\mathrm{CF}$ is the contamination factor and $\mathrm{n}$ designates the number of metals examined. IPI and PLI in Table 6 categorize the lakes on their respective scales in accordance to [50] [52] respectively. 
Table 4. Geochemical index ( $\mathrm{I}_{\text {geo }}$ ) measure of elements (Macias et al., 2006).

\begin{tabular}{|c|c|c|c|c|}
\hline Element & $\mathrm{I}_{\text {geo [COMBINED] }}$ & $\mathrm{I}_{\text {geo }}[\mathrm{ANCHAR}]$ & $\mathrm{I}_{\text {geo }[\mathrm{DAL}]}$ & Interpretation \\
\hline $\mathrm{Al}$ & -3.59 & -3.58 & -3.59 & Unpolluted $(\leq 0)$ \\
\hline As & 2.93 & 3.14 & 2.76 & $\begin{array}{c}\text { Moderately to highly polluted } \\
\text { ( } \leq 3 \text { but an char lake highly polluted }(\leq 4)\end{array}$ \\
\hline $\mathrm{Cd}$ & 0.61 & 0.44 & 0.74 & Unpolluted to moderately polluted $(\leq 1)$ \\
\hline Co & -0.34 & -0.25 & -0.39 & Unpolluted $(\leq 0)$ \\
\hline $\mathrm{Cr}$ & -0.17 & -0.06 & -0.23 & Unpolluted $(\leq 0)$ \\
\hline $\mathrm{Cu}$ & 1.91 & 1.88 & 1.94 & Moderately polluted $(\leq 2)$ \\
\hline $\mathrm{Fe}$ & -1.51 & -1.45 & -1.59 & Unpolluted $(\leq 0)$ \\
\hline $\mathrm{Mn}$ & -1.06 & -0.89 & -1.16 & Unpolluted $(\leq 0)$ \\
\hline $\mathrm{Ni}$ & -0.58 & -0.5 & -0.64 & Unpolluted $(\leq 0)$ \\
\hline $\mathrm{Pb}$ & -0.86 & -1.03 & -0.75 & Unpolluted $(\leq 0)$ \\
\hline Sn & 0.62 & 1.1 & 0.18 & $\begin{array}{l}\text { Unpolluted to moderately polluted }(\leq 1) \\
\text { But anchar lake moderately polluted }(\leq 2)\end{array}$ \\
\hline $\mathrm{Zn}$ & 3.19 & 3.31 & 3.11 & Highly polluted $(\leq 4)$ \\
\hline
\end{tabular}

Table 5. Contamination factor (CF) of elements (Raj and Jayaprakash, 2007).

\begin{tabular}{ccccc}
\hline ELEMENT & $\mathrm{CF}_{\text {[COMBINED }]}$ & $\mathrm{CF}_{\text {[ANCHAR LAKE }]}$ & $\mathrm{CF}_{[\mathrm{DAL} \text { LAKE }]}$ & Interpretation \\
\hline $\mathrm{Al}$ & 0.12 & 0.13 & 0.12 & Uncontaminated $<1$ \\
$\mathrm{As}$ & 11.41 & 13.23 & 10.19 & Contaminated $>1$ \\
$\mathrm{Cd}$ & 2.35 & 2.04 & 2.51 & Contaminated $>1$ \\
$\mathrm{Co}$ & 1.20 & 1.26 & 1.14 & Contaminated $>1$ \\
$\mathrm{Cr}$ & 1.34 & 1.44 & 1.28 & Contaminated $>1$ \\
$\mathrm{Cu}$ & 5.66 & 5.52 & 5.75 & Contaminated $>1$ \\
$\mathrm{Fe}$ & 0.52 & 0.55 & 0.50 & Uncontaminated $<1$ \\
$\mathrm{Mn}$ & 0.72 & 0.81 & 0.67 & Uncontaminated $<1$ \\
$\mathrm{Ni}$ & 1.00 & 1.06 & 0.96 & Uncontaminated $<1$ \\
$\mathrm{~Pb}$ & 0.83 & 0.73 & 0.89 & Uncontaminated $<1$ \\
$\mathrm{Sn}$ & 2.31 & 3.23 & 1.70 & Contaminated $>1$ \\
$\mathrm{Zn}$ & 13.73 & 14.86 & 12.99 & Contaminated $>1$ \\
\hline
\end{tabular}

Table 6. Integrated pollution index (IPI) and pollution load index (PLI) categorization of the lakes (Wei and Yang, 2010; Zhang et al., 2011).

\begin{tabular}{ccccc}
\hline Index & Combined & Anchar lake & Dal lake & Interpretation \\
\hline IPI & 3.43 & 3.74 & 3.22 & high level of pollution $(2$ to $\leq 5)$ \\
PLI & 1.23 & 1.26 & 1.21 & unpolluted to moderately polluted $(1$ to $\leq 2)$ \\
\hline
\end{tabular}


5) Sediment Quality Guidelines (SQG's) including Threshold Effect Level (TEL), Effects Range Low (ERL), Lowest Effect Level (LEL), Probable Effect Concentrations (PEC) and Threshold Effect Concentrations (TEC) benchmark connotations include the final corollaries. SQG's include chemical specific numerical criterion or standard or guideline or value or indicator or alert/action/threshold range levels above which site contamination or ecological effect occurrence are expected. Such a quantitative index or characteristic concentration when evaluated demonstrates the current state, quality or ecological trend of a system for its strategic regulatory management practices. Adverse effects are rarely observed due to elements $<$ TEL or $<$ ERL and no potential ecological risks are associated below PEC or TEC while acceptable effects occur at $<$ LEL. These SQG's are compared with the observed mean values for various elements in Table 7 in order to ascertain their pollution status and associated ecological risks [53] [54].

\section{Discussion}

The sediment characterisation and comparison provide an insight into its influences on the hydro-geomorphological setting of a lentic system. The abiotic quiescent zone of sediments is a suitable long-term indicator of lake environmental conditions [55] and [56]. Sediment nutrient constitution corresponds to catchment land use [57]. They provide settling space for water carried elements, both acquired and innate, in the form of ions, organic/inorganic-complexes and dissolved/suspended-matter associations [58]. Sediments reflect weaker source but stronger sink behaviour and capacity [26] depicted via transformations of adsorption/desorption, mineralization/demineralization, bioassimilation and burial phenomenon. Alkaline $\mathrm{pH}$ records of the sediment in general determine the catchment calcite predominance [59] whereas slight summer diminution is temperature improved OM decomposition effect. [60] labelled sediment $\mathrm{pH}$ as

Table 7. Sediment quality guidelines (MacDonald et al., 2000; Maanan et al., 2015): threshold effect level (TEL); effects range low (ERL); lowest effect level (LEL); probable effect concentrations (PEC); threshold effect concentrations (TEC).

\begin{tabular}{ccccccc}
\hline \multicolumn{6}{c}{ Sediment Quality Guidelines $\left[\mathrm{mg} \cdot \mathrm{Kg}^{-1}\right.$ or ppm or $\left.\mu \mathrm{g} \cdot \mathrm{g}^{-1}\right]$} \\
\hline ELEMENT & TEL & ERL & LEL & PEC & TEC & OBSERVED MEAN \\
\hline $\mathrm{As}$ & 5.9 & 33 & 6 & $*$ & $*$ & 17.1 \\
$\mathrm{Cd}$ & 0.6 & 5 & 0.6 & 5 & 1 & 0.2 \\
$\mathrm{Cr}$ & 37.3 & 80 & 26 & 110 & 43 & 114.1 \\
$\mathrm{Cu}$ & 35.7 & 70 & 16 & 150 & 32 & 141.5 \\
$\mathrm{~Pb}$ & 35 & 35 & 31 & 130 & 36 & 13.3 \\
$\mathrm{Hg}$ & 0.17 & 0.15 & 0.2 & $*$ & $*$ & $*$ \\
$\mathrm{Ni}$ & 18 & 30 & 16 & 49 & 23 & 50.0 \\
$\mathrm{Zn}$ & 123 & 120 & 120 & 460 & 120 & 975.2
\end{tabular}

( ${ }^{*}$ indicates unknown value). 
the principal factor enacting nutrient accessibility and movement. The seasonal organic C changes in sediments aptly describe [60] pattern of temperature induced decrement during summers fulfilling the mineralization promotion. The analysis of superficial sediment chemical characters reveals connections with trophic index [61] [62]. Besides, [63] and [64] evidenced eutrophication influence on $\mathrm{C}$ flow in lakes to the effect of $0.6 \mathrm{Pg} \cdot \mathrm{Y}^{-1}$ global OC burial estimate by [65]. The typical $<10 \mathrm{C} / \mathrm{N}$ implies autochthonous OM [16], besides low decomposition rates controlled by $\mathrm{N}$ budgeting and speciation via biochemical (enzyme and $\mathrm{pH}$ ) fluctuations [66] under alkaline conditions. Its possible reason could be $\mathrm{NH}_{4}{ }^{+}$microbial preference instead of $\mathrm{NO}_{3}^{-}$stimulating decomposition [67] despite eutrophied state. $\mathrm{NO}_{3}^{-}$exacerbations also shift decomposer community structure from fungal to bacterial causing $\mathrm{OM}$ decomposition decline [68]. Hence, eutrophied shallow lakes favour C sequestration. Surface sediments harbouring maximum $\mathrm{OM}$ profoundly determine biogeochemical cycling of major, minor and trace elements [16]. Significant correlation occurred for conductivity with $\mathrm{OC}$ and $\mathrm{OM}$ as the latter serves an established source for nutrient ions. Similar is the case with sediment OC, OM and TN as being complementary to one another.

Improved N: P ratios parallel chronic nitrogen influx in P-limited lakes [69], however, N-limited lakes suffer greater eutrophication catastrophes [70]. Higher temperature and lower N: $\mathrm{P}$ ratio during summer develop the $\mathrm{P}$ internal loading process. This $\mathrm{P}$ recycling mediates via degradation (oxic), denitrification and sulphate reduction [71]. Nonetheless, higher $\mathrm{Al}, \mathrm{Ca}$ and Fe proportions in sediments inactivate P mobilization [72]. Curbing the external $\mathrm{N}$ and P loads is effective in remediation but the sediment internal loading supplement compensates the loss [73]. Meanwhile sediment dredging is beneficial for internal nutrient deloading only after the external inputs are checked [74]. Trace metals bound to OM or Fe/Mn-oxides [75] separate on their decomposition and reductive dissolution respectively near hypolimnion-sediment overlap [71]. A comparative of sediment: water compartmentalization for different elements exhibit more retention potential for the sediment component conforming their sink-selves. Assuming the immensity and multifaceted networking in in situ conditions only a slight inconsistent inter-seasonal variance of $\mathrm{Ca}, \mathrm{Cl}, \mathrm{K}, \mathrm{Mg}$, $\mathrm{Na}, \mathrm{P}$ and Si were observed. But BIC, conductivity, $\mathrm{pH}, \mathrm{OM}, \mathrm{TN}$ and $\mathrm{C} / \mathrm{N}$ fluxed more on account of additional compartmental exchange quanta. A general gradual decline in nutrient concentration till culmination of active macrophytic growth phase can be associated with active/passive bioaccumulation or anoxic release from sediments [76].

Devoid of any universal sediment pollution indicator or guideline, multiple approaches were applied on the recorded holistic seasonal and site contents of micro and trace elements [77]. The EF differentiated very high anthropogenic contamination of As, significant in case of $\mathrm{Cu}$ and none for $\mathrm{Al}$ [77]. $\mathrm{I}_{\text {geo }}$ measure indicates $\mathrm{Zn}$ as highly polluting contaminant, As as moderate to highly polluting pollutant and $\mathrm{Cu}$ polluting moderately [44]. In the context of IPI and PLI, the 
selected sites and lakes exhibit moderate metal contamination [79]. CF calculations scale contamination with respect to $\mathrm{As}, \mathrm{Cd}, \mathrm{Co}, \mathrm{Cr}, \mathrm{Cu}, \mathrm{Sn}$ and $\mathrm{Zn}$ [80]. Furthermore, the observed mean concentration of $\mathrm{Cr}$, $\mathrm{Ni}$ and $\mathrm{Zn}$ exceed the given sediment quality guidelines posing particular potential ecological risks [81]. However, $\mathrm{Cd}$ and $\mathrm{Pb}$ don't transcend them. Again As is below ERL and $\mathrm{Cu}$ lags in PEC [54] [82]. A generalization of the above indices elucidates the source of contaminants to be chiefly anthropogenic, degrading the sediment profile with hazardous consequences for the dependent biota in the offing [83] [84]. The lower Ca: Al values also suggest ex situ human cause for PTE transport to the designated lacustrine sites [26]. Nonetheless, the mobility of PTE's is effectively curtailed by OM enriched sediments and calcite co-precipitation [85].

\section{Acknowledgements}

The authors acknowledge Quality Control cum Leaf Tissue Analysis Lab, Sheri Kashmir Agricultural University of Science and Technology (SKAUST), Srinagar-191121; Central Instrumentation Facility (CIF), Pondicherry University-605014 and Indian Institute of Technology and Management (IITM), Chennai-600036 for facilitating lab and instrumentation services.

\section{Conflicts of Interest}

The authors declare no conflicts of interest regarding the publication of this paper.

\section{References}

[1] Dean, J.R., Eastwood, W.J., Roberts, N., Jones, M.D., Yiğitbaşığlu, H., Allcock, S.L. and Leng, M.J. (2015) Tracking the Hydro-Climatic Signal from Lake to Sediment: A Field Study from Central Turkey. Journal of Hydrology, 529, 608-621. https://doi.org/10.1016/j.jhydrol.2014.11.004

[2] Suresh, G., Sutharsan, P., Ramasamy, V. and Venkatachalapathy, R. (2012) Assessment of Spatial Distribution and Potential Ecological Risk of the Heavy Metals in Relation to Granulometric Contents of Veeranam Lake Sediments, India. Ecotoxicology and Environmental Safety, 84, 117-124. https://doi.org/10.1016/j.ecoenv.2012.06.027

[3] Nilin, J., Moreira, L.B., Aguiar, J.E., Marins, R., de Souza Abessa, D.M., da Cruz Lotufo, T.M. and Costa-Lotufo, L.V. (2013) Sediment Quality Assessment in a Tropical Estuary: The Case of Ceará River, Northeastern Brazil. Marine Environmental Research, 91, 89-96. https://doi.org/10.1016/j.marenvres.2013.02.009

[4] Rothwell, J.J., Dise, N.B., Taylor, K.G., Allott, T.E.H., Scholefield, P., Davies, H. and Neal, C. (2010) A Spatial and Seasonal Assessment of River Water Chemistry across North West England. Science of the Total Environment, 408, 841-855. https://doi.org/10.1016/j.scitotenv.2009.10.041

[5] Manap, N. and Voulvoulis, N. (2015) Environmental Management for Dredging Sediments-The Requirement of Developing Nations. Journal of Environmental Management, 147, 338-348. https://doi.org/10.1016/j.jenvman.2014.09.024

[6] Lenzi, M., Gennaro, P., Renzi, M., Persia, E. and Porrello, S. (2012) Spread of Alsidium corallinum C. Ag. in a Tyrrhenian Eutrophic Lagoon Dominated by Oppor- 
tunistic Macroalgae. Marine Pollution Bulletin, 64, 2699-2707. https://doi.org/10.1016/j.marpolbul.2012.10.004

[7] Chon, H.S., Ohandja, D.G. and Voulvoulis, N. (2012) The Role of Sediments as a Source of Metals in River Catchments. Chemosphere, 88, 1250-1256.

https://doi.org/10.1016/j.chemosphere.2012.03.104

[8] Kraus, T.E., Bergamaschi, B.A., Hernes, P.J., Doctor, D., Kendall, C., Downing, B.D. and Losee, R.F. (2011) How Reservoirs Alter Drinking Water Quality: Organic Matter Sources, Sinks, and Transformations. Lake and Reservoir Management, 27, 205-219. https://doi.org/10.1080/07438141.2011.597283

[9] Banks, J.L., Ross, D.J., Keough, M.J., Eyre, B.D. and Macleod, C.K. (2012) Measuring Hypoxia Induced Metal Release from Highly Contaminated Estuarine Sediments during a 40-Day Laboratory Incubation Experiment. Science of the Total Environment, 420, 229-237. https://doi.org/10.1016/j.scitotenv.2012.01.033

[10] Burgin, A.J. and Hamilton, S.K. (2007) Have We Overemphasized the Role of Denitrification in Aquatic Ecosystems? A Review of Nitrate Removal Pathways. Frontiers in Ecology and the Environment, 5, 89-96. https://doi.org/10.1890/1540-9295(2007)5[89:HWOTRO]2.0.CO;2

[11] Nizzoli, D., Carraro, E., Nigro, V. and Viaroli, P. (2010) Effect of Organic Enrichment and Thermal Regime on Denitrification and Dissimilatory Nitrate Reduction to Ammonium (DNRA) in Hypolimnetic Sediments of Two Lowland Lakes. Water Research, 44, 2715-2724. https://doi.org/10.1016/j.watres.2010.02.002

[12] Akin, B.S., Atıc1, T., Katircioglu, H. and Keskin, F. (2010) Investigation of Water Quality on Gökçekaya Dam Lake Using Multivariate Statistical Analysis, in Eskişehir, Turkey. Environmental Earth Sciences, 63, 1251-1261. https://doi.org/10.1007/s12665-010-0798-6

[13] Veronesi, M.L., Barbieri, A. and Hanselmann, K.W. (2002) Phosphorus, Carbon and Nitrogen Enrichment during Sedimentation in a Seasonally Anoxic Lake (Lake Lugano, Switzerland). Journal of Limnology, 61, 215-223. https://doi.org/10.4081/jlimnol.2002.215

[14] Cole, J.J., Prairie, Y.T., Caraco, N.F., McDowell, W.H., Tranvik, L.J., Striegl, R.G. and Melack, J. (2007) Plumbing the Global Carbon Cycle: Integrating Inland Waters into the Terrestrial Carbon Budget. Ecosystems, 10, 172-185.

https://doi.org/10.1007/s10021-006-9013-8

[15] von Wachenfeldt, E., Sobek, S., Bastviken, D. and Tranvik, L.J. (2008) Linking Allochthonous Dissolved Organic Matter and Boreal Lake Sediment Carbon Sequestration: The Role of Light Mediated Flocculations. Limnology and Oceanography, 53, 2416-2426. https://doi.org/10.4319/lo.2008.53.6.2416

[16] Wetzel, R.G. (2001) Land-Water Interfaces: Larger Plants. In: Wetzel, R., Ed., Limnology, 3rd Edition, Academic Press, San Diego, 731-783.

[17] Thorén, A.K., Legrand, C. and Tonderski, K.S. (2004) Temporal Export of Nitrogen from a Constructed Wetland: Influence of Hydrology and Senescing Submerged Plants. Ecological Engineering, 23, 233-249.

https://doi.org/10.1016/j.ecoleng.2004.09.007

[18] Yun, S.L., Kim, S.J., Park, Y.J., Kang, S.W., Kwak, P.J., Ko, J.J. and Ahn, J.H. (2007) Evaluation of Capping Materials for the Stabilization of Contaminated Sediments. Materials Science Forum, 544, 565-568.

[19] Dienemann, H., Dienemann, C. and Dudel, E.G. (2006) Influence of Allochthonous Plant Litter on the Fixation of Uranium in Sediments. In: Uranium in the Environment, Springer, Berlin Heidelberg, 149-157. 
https://doi.org/10.1007/3-540-28367-6_14

[20] Ross, J.H. and Dudel, E.G. (2008) Uranium Loads and Accumulation in a Mine Water Contaminated Wetland. In: Rapantova, N. and Hrkal, Z., Eds., Mine Water and the Environment, Technical University of Ostrava, Ostrava, 225-228.

[21] Balkis, N., Aksu, A., Okuş, E. and Apak, R. (2010) Heavy Metal Concentrations in Water, Suspended Matter, and Sediment from Gökova Bay, Turkey. Environmental Monitoring and Assessment, 167, 359-370. https://doi.org/10.1007/s10661-009-1055-x

[22] Korfali, S.I. and Davies, B.E. (2004) Speciation of Metals in Sediment and Water in a River Underlain by Limestone: Role of Carbonate Species for Purification Capacity of Rivers. Advances in Environmental Research, 8, 599-612. https://doi.org/10.1016/S1093-0191(03)00033-9

[23] Swarnalatha, K., Letha, J., Ayoob, S. and Nair, A.G. (2015) Risk Assessment of Heavy Metal Contamination in Sediments of a Tropical Lake. Environmental Monitoring and Assessment, 187, 322. https://doi.org/10.1007/s10661-015-4558-7

[24] Hiller, E., Jurkovič, L. and Šutriepka, M. (2010) Metals in the Surface Sediments of Selected Water Reservoirs, Slovakia. Bulletin of Environmental Contamination and Toxicology, 84, 635-640. https://doi.org/10.1007/s00128-010-0008-y

[25] Martín-Puertas, C., Valero-Garcés, B.L., Mata, M.P., Moreno, A., Giralt, S., Martínez-Ruiz, F. and Jiménez-Espejo, F. (2009) Geochemical Processes in a Mediterranean Lake: A High-Resolution Study of the Last 4,000 Years in Zonar Lake, Southern Spain. Journal of Paleolimnology, 46, 405-421.

https://doi.org/10.1007/s10933-009-9373-0

[26] Ammar, R., Kazpard, V., Wazne, M., El Samrani, A.G., Amacha, N., Saad, Z. and Chou, L. (2015) Reservoir Sediments: A Sink or Source of Chemicals at the Surface Water-Groundwater Interface. Environmental Monitoring and Assessment, 187, 579. https://doi.org/10.1007/s10661-015-4791-0

[27] Pejman, A., Bidhendi, G.N., Ardestani, M., Saeedi, M. and Baghvand, A. (2015) A New Index for Assessing Heavy Metals Contamination in Sediments: A Case Study. Ecological Indicators, 58, 365-373. https://doi.org/10.1016/j.ecolind.2015.06.012

[28] Abubakr, A. and Kundangar, M.R.D. (2009) Three Decades of Dal Lake Pollution. Restoration, Ecology, Environment \&Conservation, 15, 825-833.

[29] Badar, B., Romshoo, S.A. and Khan, M.A. (2012) Integrating Biophysical and Socioeconomic Information for Prioritizing Watersheds in a Kashmir Himalayan Lake: A Remote Sensing and GIS Approach. Environmental Monitoring and Assessment, 185, 6419-6445. https://doi.org/10.1007/s10661-012-3035-9

[30] Zargar, U.R., Chishti, M.Z., Yousuf, A.R. and Fayaz, A. (2012) Infection Level of Monogenean Gill Parasite, Diplozoon kashmirensis (Monogenea, Polyopisthocotylea) in the Crucian Carp, Carassius carassius from Lake Ecosystems of an Altered Water Quality: What Factors Do Have an Impact on the Diplozoon Infection? Veterinary Parasitology, 189, 218-226. https://doi.org/10.1016/j.vetpar.2012.04.029

[31] Rashid, I., Romshoo, S.A., Amin, M., Khanday, S.A. and Chauhan, P. (2016) Linking Human-Biophysical Interactions with the Trophic Status of Dal Lake, Kashmir Himalaya, India. Limnologica-Ecology and Management of Inland Waters, 62, 84-96. https://doi.org/10.1016/j.limno.2016.11.008

[32] Ryan, J., Estefan, G. and Rashid, A. (2007) Soil and Plant Analysis Laboratory Manual. International Center for Agricultural Research in the Dry Areas (ICARDA), Aleppo. 
[33] Gupta, P.K. (2004) Soil, Plant, Water and Fertilizer Analysis. Agro Botanica, Vyas Nagar, Bikaner.

[34] Radojevic, M. and Bashkin, V.N. (2006) Practical Environmental Analysis. 2nd Edition, The Royal Society of Chemistry, Thomas Graham House, Cambridge.

[35] Estefan, G., Sommer, R. and Ryan, J. (2013) Methods of Soil, Plant and Water Analysis. International Center for Agricultural Research in the Dry Areas (ICARDA), Beirut.

[36] Alloway, B.J. (1995) Heavy Metals in Soils. 2nd Edition, Blackie Academic and Professional, London. https://doi.org/10.1007/978-94-011-1344-1

[37] Reimann, C., Filzmoser, P., Garrett, R. and Dutter, R. (2008) Statistical Data Analysis Explained: Applied Environmental Statistics with R. John Wiley \& Sons, Hoboken. https://doi.org/10.1002/9780470987605

[38] Greenacre, M. and Primicerio, R. (2013) Multivariate Analysis of Ecological Data. Fundacion BBVA.

[39] Choi, K.Y., Kim, S.H., Hong, G.H. and Chon, H.T. (2012) Distributions of Heavy Metals in the Sediments of South Korean Harbors. Environmental Geochemistry and Health, 34, 71-82. https://doi.org/10.1007/s10653-011-9413-3

[40] Guerra-García, J.M. and García-Gómez, J.C. (2005) Assessing Pollution Levels in Sediments of a Harbour with Two Opposing Entrances. Environmental Implications. Journal of Environmental Management, 77, 1-11. https://doi.org/10.1016/j.jenvman.2005.01.023

[41] Taylor, S.R. and McLennan, S.M. (1995) The Geochemical Evolution of the Continental Crust. Reviews of Geophysics, 33, 241-265. https://doi.org/10.1029/95RG00262

[42] Goher, M.E., Farhat, H.I., Abdo, M.H. and Salem, S.G. (2014) Metal Pollution Assessment in the Surface Sediment of Lake Nasser, Egypt. The Egyptian Journal of Aquatic Research, 40, 213-224. https://doi.org/10.1016/j.ejar.2014.09.004

[43] Han, Y.M., Du, P.X., Cao, J.J. and Posmentier, E.S. (2006) Multivariate Analysis of Heavy Metal Contamination in Urban Dusts of Xi'an, Central China. Science of the Total Environment, 355, 176-186. https://doi.org/10.1016/j.scitotenv.2005.02.026

[44] Chandrasekaran, A., Ravisankar, R., Harikrishnan, N., Satapathy, K.K., Prasad, M.V.R. and Kanagasabapathy, K.V. (2015) Multivariate Statistical Analysis of Heavy Metal Concentration in Soils of Yelagiri Hills, Tamilnadu, India-Spectroscopical Approach. Spectrochimica Acta Part A: Molecular and Biomolecular Spectroscopy, 137, 589-600. https://doi.org/10.1016/j.saa.2014.08.093

[45] Müller, G. (1979) Schwermetalle in den Sedimenten des Rheins-Veränderungen seit 1971. Umschau, 79, 778-783.

[46] Müller, G. (1981) Die Schwermetallbelastung der sedimente des Neckars und seiner Nebenflusse: Eine Bestandsaufnahme. Chemical Zeitung, 105, 157-164.

[47] Macias, C.G., Schifter, I., Lluch-Cota, D.B., Mendez-Rodriguez, L. and Hernandez-Vazquez, S. (2006) Distribution, Enrichment and Accumulation of Heavy Metals in Coastal Sediments of Salina Cruz Bay, Mexico. Environmental Monitoring and Assessment, 118, 211-230. https://doi.org/10.1007/s10661-006-1492-8

[48] Mediolla, L.L., Domingues, M.C.D. and Sandoval, M.R.G. (2008) Environmental Assessment of and Active Tailings Pile in the State of Mexico (Central Mexico). Research Journal of Environmental and Earth Sciences, 2, 197-208.

[49] Raj, S.M. and Jayaprakash, M. (2007) Distribution and Enrichment of Trace Metals in Marine Sediments of Bay of Bengal, off Ennore, South-East Coast of India. Envi- 
ronmental Geology, 56, 207-217. https://doi.org/10.1007/s00254-007-1156-1

[50] Wei, B. and Yang, L. (2010) A Review of Heavy Metal Contaminations in Urban Soils, Urban Road Dusts and Agricultural Soils from China. Microchemical Journal, 94, 99-107. https://doi.org/10.1016/j.microc.2009.09.014

[51] Gong, Q., et al. (2008) Calculating Pollution Indices by Heavy Metals in Ecological Geochemistry Assessment and a Case Study in Parks of Beijing. Journal of China University of Geosciences, 19, 230-241. https://doi.org/10.1016/S1002-0705(08)60042-4

[52] Zhang, C., Qiao, Q., Piper, J.D. and Huang, B. (2011) Assessment of Heavy Metal Pollution from a Fe-Smelting Plant in Urban River Sediments Using Environmental Magnetic and Geochemical Methods. Environmental Pollution, 159, 3057-3070. https://doi.org/10.1016/j.envpol.2011.04.006

[53] MacDonald, D.D., Ingersoll, C.G. and Berger, T.A. (2000) Development and Evaluation of Consensus-Based Sediment Quality Guidelines for Freshwater Ecosystems. Archives of Environmental Contamination and Toxicology, 39, 20-31. https://doi.org/10.1007/s002440010075

[54] Maanan, M., Saddik, M., Maanan, M., Chaibi, M., Assobhei, O. and Zourarah, B. (2015) Environmental and Ecological Risk Assessment of Heavy Metals in Sediments of Nador Lagoon, Morocco. Ecological Indicators, 48, 616-626.

https://doi.org/10.1016/j.ecolind.2014.09.034

[55] Downing, J.A., Cole, J.J., Middelburg, J.J., Striegl, R.G., Duarte, C.M., Kortelainen, P. and Laube, K.A. (2008) Sediment Organic Carbon Burial in Agriculturally Eutrophic Impoundments over the Last Century. Global Biogeochemical Cycles, 22, 1-10. https://doi.org/10.1029/2006GB002854

[56] Wagner, B., Lotter, A.F., Nowaczyk, N., Reed, J.M., Schwalb, A., Sulpizio, R. and Zanchetta, G. (2009) A 40,000-Year Record of Environmental Change from Ancient Lake Ohrid (Albania and Macedonia). Journal of Paleolimnology, 41, 407-430. https://doi.org/10.1007/s10933-008-9234-2

[57] Knoll, L.B., Vanni, M.J., Renwick, W.H. and Kollie, S. (2014) Burial Rates and Stoichiometry of Sedimentary Carbon, Nitrogen and Phosphorus in Midwestern US Reservoirs. Freshwater Biology, 59, 2342-2353. https://doi.org/10.1111/fwb.12438

[58] Schaller, J., Vymazal, J. and Brackhage, C. (2013) Retention of Resources (Metals, Metalloids and Rare Earth Elements) by Autochthonously/Allochthonously Dominated Wetlands: A Review. Ecological Engineering, 53, 106-114.

https://doi.org/10.1016/j.ecoleng.2012.12.021

[59] Singh, S.P. and Singh, B.P. (2010) Geothermal Evolution of the Evaporite-Bearing Sequences of the Lesser Himalaya, India.

[60] Urban, N.R., Brezonik, P.L., Baker, L.A. and Sherman, L.A. (2009) Sulfate Reduction and Diffusion in Sediments of Little Rock Lake, Wisconsin. Limnology and Oceanography, 39, 797-815. https://doi.org/10.1016/j.ecoleng.2012.12.021

[61] Gudasz, C., Bastviken, D., Steger, K., Premke, K., Sobek, S. and Tranvik, L.J. (2010) Temperature-Controlled Organic Carbon Mineralization in Lake Sediments. Nature, 466, 478-481. https://doi.org/10.1038/nature09186

[62] de Vicente, I., Guerrero, F. and Cruz-Pizarro, L. (2010) Chemical Composition of Wetland Sediments as an Integrator of Trophic State. Aquatic Ecosystem Health \& Management, 13, 99-103. https://doi.org/10.1080/14634980903566816

[63] Lazzarino, J.K., Bachmann, R.W., Hoyer, M.V. and Canfield, D.E. (2009) Carbon Dioxide Supersaturation in Florida Lakes. Hydrobiologia, 627, 169-180. 
https://doi.org/10.1007/s10750-009-9723-y

[64] Heathcote, A.J. and Downing, J.A. (2012) Impacts of Eutrophication on Carbon Burial in Freshwater Lakes in an Intensively Agricultural Landscape. Ecosystems, 15, 60-70. https://doi.org/10.1007/s10021-011-9488-9

[65] Tranvik, L.J., Downing, J.A., Cotner, J.B., Loiselle, S.A., Striegl, R.G., Ballatore, T.J. and Kortelainen, P.L. (2009) Lakes and Reservoirs as Regulators of Carbon Cycling and Climate. Limnology and Oceanography, 54, 2298-2314. https://doi.org/10.4319/lo.2009.54.6_part_2.2298

[66] Min, K., Kang, H. and Lee, D. (2011) Effects of Ammonium and Nitrate Additions on Carbon Mineralization in Wetland Soils. Soil Biology and Biochemistry, 43, 2461-2469. https://doi.org/10.1016/j.soilbio.2011.08.019

[67] Garland, J.L., Mackowiak, C.L. and Zabaloy, M.C. (2010) Organic Waste Amendment Effects on Soil Microbial Activity in a Corn-Rye Rotation: Application of a New Approach to Community-Level Physiological Profiling. Applied Soil Ecology, 44, 262-269. https://doi.org/10.1016/j.apsoil.2010.01.003

[68] Allison, S.D., Czimczik, C.I. and Treseder, K.K. (2008) Microbial Activity and Soil Respiration under Nitrogen Addition in Alaskan Boreal Forest. Global Change Biology, 14, 1156-1168. https://doi.org/10.1111/j.1365-2486.2008.01549.x

[69] Elser, J.J., Andersen, T., Baron, J.S., Bergström, A.K., Jansson, M., Kyle, M. and Hessen, D.O. (2009) Shifts in Lake N: P Stoichiometry and Nutrient Limitation Driven by Atmospheric Nitrogen Deposition. Science, 326, 835-837. https://doi.org/10.1126/science.1176199

[70] Abell, J.M., Özkundakci, D. and Hamilton, D.P. (2010) Nitrogen and Phosphorus Limitation of Phytoplankton Growth in New Zealand Lakes: Implications for Eutrophication Control. Ecosystems, 13, 966-977.

https://doi.org/10.1007/s10021-010-9367-9

[71] Canavan, R.W., Slomp, C.P., Jourabchi, P., Van Cappellen, P., Laverman, A.M. and Van den Berg, G.A. (2006) Organic Matter Mineralization in Sediment of a Coastal Freshwater Lake and Response to Salinization. Geochimica et Cosmochimica Acta, 70, 2836-2855. https://doi.org/10.1016/j.gca.2006.03.012

[72] Smolders, A.J.P., Lamers, L.P.M., Lucassen, E.C.H.E.T., Van der Velde, G. and Roelofs, J.G.M. (2006) Internal Eutrophication: How It Works and What to Do about It-A Review. Chemistry and Ecology, 22, 93-111.

https://doi.org/10.1080/02757540600579730

[73] Jing, L.D., Wu, C., Liu, J., Wang, H. and Ao, H. (2013) The Effects of Dredging on Nitrogen Balance in Sediment-Water Microcosms and Implications to Dredging Projects. Ecological Engineering, 52, 167-174. https://doi.org/10.1016/j.ecoleng.2012.12.109

[74] Jing, L., Liu, X., Bai, S., Wu, C., Ao, H. and Liu, J. (2015) Effects of Sediment Dredging on Internal Phosphorus: A Comparative Field Study Focused on Iron and Phosphorus Forms in Sediments. Ecological Engineering, 82, 267-271. https://doi.org/10.1016/j.ecoleng.2015.04.099

[75] Turner, A., Millward, G.E. and Le Roux, S.M. (2004) Significance of Oxides and Particulate Organic Matter in Controlling Trace Metal Partitioning in a Contaminated Estuary. Marine Chemistry, 88, 179-192. https://doi.org/10.1016/j.marchem.2004.03.008

[76] Selig, U. and Schlungbaum, G. (2003) Characterisation and Quantification of Phosphorus Release from Profundal Bottom Sediments in Two Dimictic Lakes 
during Summer Stratification. Journal of Limnology, 62, 151-162.

https://doi.org/10.4081/jlimnol.2003.151

[77] Lopes, M.L., Rodrigues, A.M. and Quintino, V. (2014) Ecological Effects of Contaminated Sediments Following a Decade of No Industrial Effluents Emissions: The Sediment Quality Triad Approach. Marine Pollution Bulletin, 87, 117-130. https://doi.org/10.1016/j.marpolbul.2014.08.004

[78] Wali, A., Kawachi, A., Bougi, M.S.M., Dhia, H.B., Isoda, H., Tsujimura, M. and Ksibi, M. (2015) Effects of Metal Pollution on Sediments in a Highly Saline Aquatic Ecosystem: Case of the Moknine Continental Sebkha (Eastern Tunisia). Bulletin of Environmental Contamination and Toxicology, 94, 511-518. https://doi.org/10.1007/s00128-015-1469-9

[79] Bastami, K.D., Neyestani, M.R., Shemirani, F., Soltani, F., Haghparast, S. and Akbari, A. (2015) Heavy Metal Pollution Assessment in Relation to Sediment Properties in the Coastal Sediments of the Southern Caspian Sea. Marine Pollution Bulletin, 92, 237-243. https://doi.org/10.1016/j.marpolbul.2014.12.035

[80] Iqbal, J., Tirmizi, S.A. and Shah, M.H. (2013) Statistical Apportionment and Risk Assessment of Selected Metals in Sediments from Rawal Lake (Pakistan). Environmental Monitoring and Assessment, 18, 729-743. https://doi.org/10.1007/s10661-012-2588-y

[81] Ji, Y., Zhang, J., Li, R., Pan, B., Zhang, L. and Chen, X. (2015) Distribution and Partitioning of Heavy Metals in Sediments of the Xinjiang River in Poyang Lake Region, China. Environmental Progress \& Sustainable Energy, 34, 713-723. https://doi.org/10.1002/ep.12054

[82] Sany, S.B.T., Hashim, R., Rezayi, M., Salleh, A. and Safari, O. (2014) A Review of Strategies to Monitor Water and Sediment Quality for a Sustainability Assessment of Marine Environment. Environmental Science and Pollution Research, 21, 813-833. https://doi.org/10.1007/s11356-013-2217-5

[83] Zhu, X., Ji, H., Chen, Y., Qiao, M. and Tang, L. (2013) Assessment and Sources of Heavy Metals in Surface Sediments of Miyun Reservoir, Beijing. Environmental Monitoring and Assessment, 185, 6049-6062. https://doi.org/10.1007/s10661-012-3005-2

[84] Yuan, Z., Taoran, S., Yan, Z. and Tao, Y. (2014) Spatial Distribution and Risk Assessment of Heavy Metals in Sediments from a Hypertrophic Plateau Lake Dianchi, China. Environmental Monitoring and Assessment, 186, 1219-1234. https://doi.org/10.1007/s10661-013-3451-5

[85] Paramasivam, K., Ramasamy, V. and Suresh, G. (2015) Impact of Sediment Characteristics on the Heavy Metal Concentration and Their Ecological Risk Level of Surface Sediments of Vaigai River, Tamilnadu, India. Spectrochimica Acta Part A: Molecular and Biomolecular Spectroscopy, 137, 397-407.

https://doi.org/10.1016/j.saa.2014.08.056 